\title{
Femten år med Oslo 96 - hva nå?
}

I 1996 innførte Det medisinske fakultet en ny studieplan som ble kalt Oslo 96. Planen ble innført etter 6-7 års grundig planlegging med bidrag fra mange og med støtte fra et samlet fakultet $(1,2)$. Den var et radikalt brudd med tidligere fagdelte studieplaner ved Norges eldste medisinske fakultet og ble lagt merke til både innad på universitetet og utenfor. Per Egil Hegge skrev i Aftenposten ved semesterstart at det var «en historisk dag for norsk medisin» (3). Hovedmålene med studieomleggingen var å ta i bruk studentaktiviserende undervisningsmetoder og legge til rette for fagintegrering. Endring av undervisningsmetoder hadde også til hensikt å bedre muligheten for refleksjon og dybdelæring. Studentene skulle med Oslo 96 gis reelle muligheter til å tenke selvstendig, til å utvikle seg gjennom et aktivt samspill med lærere, medstudenter og pasienter - ikke bare bli undervist. Problembasert læring (PBL) ble valgt særlig ut fra målet om fagintegrasjon. Allmennmedisin fikk utvidet plass tilsvarende sin status som det tredje kliniske hovedfaget. Kommunikasjonsopplæringen ble styrket. Organiseringen av studiet i tverrfaglige semestre medførte behov for tydeligere plassering av faglig ansvar og profesjonalisering av den administrative ledelsen. Evalueringer og forskningsrapporter tydet på endringer i ønsket retning (4-6).

Hvordan er situasjonen i dag, femten år etter starten? Det er dessverre vanlig at innovative studieplaner rammes av regresjon til gjennomsnittet (det som ofte omtales som «regression to the mean») - dvs. gjeninnføring av gamle løsninger og reduksjon av de krevende nye elementene. Heller ikke Oslo 96 ser ut til å slippe unna. De senere årene er det for eksempel gjort endringer i retning av økte gruppestørrelser (problembasert læring, klinisk mdisin), $ø k t$ antall forelesninger og svekkelse av integrerende tiltak. Moust og medarbeidere beskrev en slik regresjon til gjennomsnittet etter 30 år med problembasert læring i Maastrict, og konkluderte med at «Disse endringene, som hver for seg er små, vil til sammen i det lange løp føre til at den innovative planen bryter sammen» (7).

Fakultetet står i dag overfor to store oppgaver når det gjelder medisinstudiet. Den ene dreier seg om ivaretakelse, den andre om utvikling. Hvis man mener at studiemodellen Oslo 96 bør videreføres, må det settes inn tiltak for å sikre at det studiet studentene opplever, er i tråd med planens verdigrunnlag og overordnede mål, og at de valgte læringsmetodene brukes optimalt. Svakheter ved planen som har vist seg gjennom årene, må forsøkes rettet opp, men ikke gjennom lite gjennomtenkte og tilfeldige endringer uten hensyn til helheten i studiet. Like viktig er utviklingen av lærerstaben for å øke kunnskap og entusiasme om studiet blant fakultetets ansatte og studenter. «Bare lærerne er viktigere enn studieplanen,» sa Peter F. Hjort i et innlegg i Tidsskriftet for mange år siden (fritt gjengitt). Anstrengelsene for å oppnå fagintegrasjon bør økes, og det må settes inn tiltak for at de mange læringsmessige mulighetene med problembasert læring utnyttes (8). Videre bør sikring og helst bedring av læringsmiljøet i den kliniske del av studiet ha høy prioritet - det er i særlig grad i møte med aktive klinikere at morgendagens leger formes.

Men mye er forandret rundt oss siden Oslo 96 ble planlagt. Dette tilsier at det er behov for mer enn vedlikehold. Én viktig videreutvikling som er iverksatt, er det integrerte opplegget for kunnskapshåndtering, ledelse og kvalitetsforbedring (KLoK). Videre bør samhandlingsreformen være en anledning til å se fordomsfritt på om studiet fortsatt er for dominert av sykehusmedisinens tenkemåte. Opplever studentene sykehusmedisinen på den ene siden og allmenn- og samfunnsmedisinen på den annen som atskilte verdener? Det er også sannsynlig at Oslo 96 i for liten grad forbereder studentene på den økende andelen gamle i befolkningen. Et siste eksempel gjelder legerollen. Det er en tendens i dag til at leger i økende grad oppfattes som funksjonærer og teknikere. Bør dette få konsekvenser for studiet? En begynnelse vil være å undersøke nærmere om «den skjulte studieplanen» stemmer med den skrevne planens mål og verdier (9).

Men det virkelig grunnleggende spørsmålet vi må stille oss er: Tilbyr vi studentene deltakelse i et læringsmiljø som gir de beste muligheter for læring og personlig vekst? Dette krever en gjennomtenkt studieplan, men først og fremst faglig sterke lærere som bryr seg om studentenes læring: «Likevel vet alle vi som underviser at det magiske øyeblikket når undervisning blir til læring avhenger av den menneskelige setting og lærerens eksempel - faktorer som har å gjøre med vekstmiljø heller enn planer og rammer påført utenfra» (10).

\section{Per Brodal}

p.a.brodal@medisin.uio.no

Avdeling for anatomi

Det medisinske fakultet

Universitetet i Oslo

Per Brodal (f. 1944) er professor i anatomi ved Universitetet i Oslo. Oppgitte interessekonflikter: Forfatteren ledet arbeidet med planleggingen og innføringen av 0slo 96 og var studiedekan i perioden 2003-06.

\section{Litteratur}

1. Universitetet i Oslo. «Oslo 96». Ny grunnutdanning for leger. Oslo: Det medisinske fakultet, Universitetet i Oslo, 1993

2. Brodal P. Oslo 96 - hva var de viktigste endringene, og hvordan har det gått? I: Lindbæk M, Straand J, red. Allmennmedisinske spor. Oslo: Unipub forlag, 2006: 113-27.

3. Hegge PE. En historisk dag for norsk medisin. Aftenposten 15.8.1996.

4. Universitetet i Oslo. Periodisk programevaluering. www.uio.no/studier/ program/medisin/studiekvalitet/periodisk/ (14.10.2011).

5. Wiers-Jenssen J, Aasland OG. Har Oslo96-reformen ført til endringer i studenttilfredshet og studieatferd? Tidsskr Nor Lægeforen 2004: 124: 2100-3.

6. Gude T, Hjortdahl P, Anvik T et al. Does change from a traditional to a new medical curriculum reduce negative attitudes among students? A quasi-experimental study. Med Teach 2005; 27: 737-9.

7. Moust JH, Van Berkel HJ, Schmidt HG. Signs of erosion: reflections on three decades of problem-based learning at Maastricht University Higher Educ 2005: 50: 665-83.

8. Schmidt HG, Rotgans JI, Yew EH. The process of problem-based learning: what works and why. Med.Educ 2011; 45: 792-806.

9. Haidet P. Stein HF. The role of the student-teacher relationship in the formation of physicians. The hidden curriculum as process. J Gen Intern Med 2006; 21 (suppl): 16-20.

10. Franklin U. The real world of technology. Concord, ON: House of Anansi Press, 1990. 